\title{
THE TIME-VARYING NATURE OF REITS
}

\author{
Bing Zhu, PhD \\ Department of Land Economy \\ University of Cambridge \\ e-mail:bz262@cam.ac.uk.
}

\begin{abstract}
This paper investigates changes in the nature of REITs by estimating the time-varying long-run relationship among securitized real estate, direct real estate, and stock performance. The informational environment of U.S. REITs has matured gradually since their introduction. As more information on this asset class has become available, the "true" nature of REITs has thus become more apparent. We find that the long-term elasticity of direct real estate total returns on REIT total returns has increased since 1980, and became significant at the beginning of the 1990s, while the elasticity of general equity total returns remained insignificant. During the 2000s, the underlying property market was able to predict nearly $30 \%$ of REIT variance in the long term. Consequently, ignoring changes in the "nature" of REITs may lead to an underestimation of the influence from the underlying property market, and misspecification of the optimal weights in the long-term inter-asset portfolio.
\end{abstract}

Key words: Time-varying cointegration, Extended Vector Error Correction Model, Direct Real Estate, Securitized Real Estate, Diversification.

JEL Classification: C58, R30.

Citation: Zhu B., 2018, The Time-Varying Nature of Reits, Real Estate Management and Valuation, vol. 26, no. 1, pp. 26-38.

DOI: 10.2478/remav-2018-0003

\section{Introduction}

Real estate investment trusts (REITs) have become one of the most important types of securitized real estate, and as such have attracted widespread attention. The REIT investment vehicle was created by U.S. Congress in 1960 which authorized a real estate ownership structure similar to that of mutual funds: a tax pass-through property investment entity. REITs allow public to gain exposure to real estate, which is generally an illiquid asset class, without sacrificing the liquidity benefits of listed equities. REITs have become a popular investment instrument as they typically provide higher yields than other equities. REITs can also serve as an effective inflation hedge and help diversify a portfolio made up of other asset classes for long-term investors. The success of the U.S. REITs prompted the development of this tax pass-through property vehicle in many countries in the world. Starting at approximately $\$ 2.5$ billion in 1983 , the total capitalization of the global property equity market had reached $\$ 1.2$ trillion by 2011, over 35\% of which was in North American, with Europe and Asia-Pacific splitting most of the rest.

This paper focuses on the changing nature of U.S. REITs. REITs have dual nature. As for listed firms, shares of REITs are publicly traded in the stock exchange. Meanwhile, REITs are also real estate firms, pure plays in the sense that their assets and activities are largely restricted to real estate. Therefore, REITs have a dual nature - the performance of REITs can be affected by the performance of both the stock market and the underlying real estate market. This paper investigates variations in the long-term investment characteristics of REITs. When the informational environment surrounding REITs has matured and their management has become more professional and precise, the "true" nature of REITs has become more apparent. Thus the long-term relationship among REITs, direct real estate, and stocks may change accordingly. 
Most previous research focused on changes in contemporaneous correlations (e.g., GHOSH, MILES, SIRMANS 1996; HOESLI, SERRANO 2007) or short-term dynamics (e.g., LIU, MEI, 1992; LING, NARANJO, 1999; Quan, TitMan, 1999; Clayton, MaCKinnon 2001; Ambrose, LeE, PeEK 2007). The general consensus was that REITs tended to be more strongly affected by the general equity market, especially after they joined the S\&P 500 index in the short term.

However, short-term return correlations do not necessarily reflect the long-term relationships with either price or total returns. These correlations, or short-term dynamics, are prone to significant instabilities over time. For example, long-run price comovements may occur even during periods when static correlation appears very low (ALEXANDER, et al., 2002). The short- and long-term dynamics may also be driven by different mechanisms. According to previous literature, in the short term, the links between REITs and other assets can be affected by investor sentiment, market frictions (AMBROSE, LEE, PEEK 2007), or extreme events (SIMON, NG 2009). But in the long term, the relationships among REITs, direct real estate, and general equity may actually be tied to the "nature" of REITs (CLAYTON, MACKINNON 2009). Therefore, changes in short-term characteristics may not hold over the long run.

This paper investigates changes in long-term investment characteristics of REITs by estimating the time-varying long-run relationship among securitized real estate, direct real estate, and stock performance. Differing from the previous literature, this paper incorporates the time-varying cointegration technique into a traditional Vector Error Correction Model. The new method can measure the change in the long-term elasticity without splitting data sample. Compared with the methods such as structure break or rolling windows, the time-varying method can capture the dynamics even within each sub-sample. Therefore, this method provides an effective way to model the gradual change in the characteristics of REITs.

Our empirical results reveal increasingly close long-term links between securitized and direct real estate, but insignificant links between REITs and general equity, despite the fact that the five-year rolling correlation coefficient between REIT and stock returns always exceeds that between REITs and direct real estate returns. During the 2000s, as the REIT market gradually matured, the long-term performance of REITs was largely determined by the underlying direct property market.

The results have implications for long-run multi-asset portfolio strategies. Recently, instead of using correlations to optimize portfolios, the cointegration technique has become more attractive to long-term investors. Compared with a returns-based portfolio method, a cointegration-based portfolio does not require rebalancing, and uses the entire information set comprised in the financial variables (Alexander et al., 2002). The change in long-term elasticity implies that the optimal long-term portfolio weights should also change accordingly. Ignoring such dynamics may lead to an underestimation of the influence from the underlying property market, and misspecification of the optimal weights in the long-term inter-asset portfolio. Generally, we find that for long-term investors, the benefits of using REITs to diversify direct real estate investments have diminished, but REITs can still serve as a suitable "alternative investment."

The remainder of this paper is organized as follows. Section 2 provides a review of previous literature, while section 3 introduces the time-varying cointegration technique. Section 4 discusses our empirical results. Section 5 concludes.

\section{Literature review}

Previous studies found generally inconsistent results for whether real estate securities are fundamentally influenced by the underlying property markets or by general stocks. The results were found to depend largely on the method, market, and/or sample used. Several studies reported high correlations for real estate securities and common stocks (see, e.g., ONG 1995; LI, WANG 1995; MORAWSKI, REHKUGLER, FƯSS 2008). Alternatively, other studies have found that real estate securities behave more like underlying property markets and less like general stocks in the long run (see, e.g., PAgliari, SCHERER, MONOPOLI 2005; WeSTERHEIDE 2006; TSAI, CHEN, Sing 2007; SCHÄTZ, SEBASTIAN 2011).

Instead of a constant relationship, some studies have investigated how the links among underlying real estate markets, real estate securities, and stocks vary over time. CLAYTON and MACKINNON (2001), for example, examine a U.S. market sample between 1978 and 1998 using a multi-factor approach. 
Although the underlying real estate does not explain REIT returns over the entire sample, they found an increase in the correlation between direct and indirect real estate.

Based on a five-year rolling window and a multifactor model, HOESLI and SERRANO (2007) analyze the relationships among real estate securities, general stocks, bonds, and direct real estate in sixteen economies. They find that the market risk premium of stock returns on REIT returns clearly decreased in nine markets. In three markets, it decreased prior to 2000 and then increased again; in four markets, it remained relatively constant.

Several other studies have shown increases in the comovements between REIT returns and general stock returns. AMBROSE, LEE and PEEK (2007) study fifteen REITs on the S\&P 500 index, and find increasing correlations among them since 2001. Their findings provide evidence of market frictions and the spillover of some non-fundamental effects, such as investor sentiment.

SIMON and NG (2009) focus on the asymmetric tail dependence between REITs and the S\&P 500 using a flexible mixed-copula approach. The tail dependence varies with normal linear correlation according to the level of dependence in the extreme event, such as, e.g., a financial crisis. They find increased dependence in the tail since 2007.

Regarding long-term dynamics GLASCOCK, LU and So (2000) estimate pairwise cointegration relationships among REIT total returns and other assets before and after 1992. They find that REITs were cointegrated with stocks during the 1992-1996 period. From 1984 to 1992, REITs were cointegrated with bond returns. They conclude that REITs behave more like stocks and less like bonds after the structural changes in the early 1990s.

MORAWSKI, REHKUGLER and FÜSS (2008) extend the data to 2008, and estimate the cointegration relationship before and after 1992. They observe that the long-term elasticity of stock total returns on REITs disappeared after 1992, but the elasticity of NPI total returns remained significant.

OIKARINEN, HOESLI and SERRANO (2011) also find a cointegration relationship between securitized and direct real estate total return indices, but no cointegration with stock total returns. By observing the deviations from the long-term relationship, they find that "a large and long-lasting deviation from the long-run relation between NAREIT and NCREIF is identified at the beginning of the "new REIT era'."

\section{Methodology}

Following JOHANSEN (1988), we apply the cointegration concept to vector autoregressive (VAR) models using a vector error correction (VEC) framework in order to analyze the dynamic relationships among the three assets. We specify the VECM model as:

$$
\Delta z_{t}=v_{t}+\alpha \beta^{\prime} z_{t-1}+\sum_{p=1}^{P} \Gamma_{p} \Delta z_{t-p}+\delta D_{t}+\varepsilon_{t}
$$

where $z_{t}=\left[R E I T_{t}, R E_{t}, S_{t}, X_{t}\right]^{\prime}$ and $\Delta z_{t}$ are the first differences of variables. We include three return indices: the REIT total return index $\left(R E I T_{t}\right)$, the direct real estate investment index $\left(R E_{t}\right)$, and the stock market performance index $\left(S_{t}\right) . X_{t}$ are the economic fundamentals. Because the observed comovements among markets may be an indirect effect of economic factors, rather than pure market interdependence, we account for the influence of fundamental variables by including them in the cointegration relationship.

Note that $\beta$ represents a matrix of the $\mathrm{r}$ cointegrating vectors, where the matrix contains the socalled loading parameter (i.e., those coefficients that describe the contribution of the $r$ long-term relationships in the individual equations). $\alpha$ is the adjustment coefficient, $v_{t}$ is the vector for the deterministic trend, the matrices $\Gamma_{i}$ represent the short-term dynamics for asset index and economic fundamentals, respectively, $D_{t}$ are the seasonal dummy variables, and $\delta$ are the corresponding coefficients. $\varepsilon_{t}$ are the error terms.

In order to capture how the long-run relationship evolves over time, we use time-varying $\beta_{t}$ instead of constant $\beta$. Equation (1) then becomes:

$$
\Delta z_{t}=v_{t}+\alpha \beta_{t}^{\prime} z_{t-1}+\sum_{p=1}^{P} \Gamma_{p} \Delta z_{t-p}+\delta D_{t}+\varepsilon_{t},
$$

In order to estimate the time-varying (TV) $\beta_{t}$, BIERENS and MARTINS (2010) propose using Chebyshev time polynomials, where $P_{i, t}(t)$ is defined as:

$$
P_{0, T}(t)=1, P_{i, T}=\sqrt{2} \cos \left(\frac{i \pi(t-0.5)}{T}\right),
$$


$t=1,2, \ldots T, i=1,2,3, \ldots$

Note that CHEBYSHEV time polynomials are orthogonal, which means, for all integers $i$ and $j$, $\frac{1}{T} \sum_{t=1}^{T} P_{i, T}(t) P_{j, T}(t)=1(i \neq j)$. Due to this orthogonality, any function $g(t)$ of discrete time $t=1,2, \ldots, T$ can be represented as:

$$
g(t)=\sum_{i=0}^{T-1} \xi_{i, T} P_{i, T}(t), \text { and } \xi_{i, T}=\frac{1}{T} \sum_{t=1}^{T} g(t) P_{i, T}(t),
$$

where $g(t)$ is decomposed linearly into components $\xi_{i, T} P_{i, T}(t)$ of decreasing smoothness. If $g(t)$ is smooth, it can be approximated quite well by:

$$
g(t)=\sum_{i=0}^{m} \xi_{i, T} P_{i, T}(t)
$$

for some fixed natural number $m<T-1$.

Substituting $\alpha \beta_{t}^{\prime}=\alpha\left(\sum_{i=0}^{m} \xi_{i, T} P_{i, T}(t)\right)^{\prime}=\alpha \xi^{\prime}$ into Equation 2, it becomes:

$$
\Delta z_{t}=v_{t}+\alpha \xi^{\prime} z_{t-1}+\sum_{p=1}^{P} \Gamma_{p} \Delta z_{t-p}+\delta D_{t}+\varepsilon_{t},
$$

For some $k \times r$ matrices $\xi_{i}, \xi_{i}^{\prime}=\left[\xi_{0}^{\prime}, \xi_{1}^{\prime}, \ldots, \xi_{m}^{\prime}\right]$ is an $r \times(m+1) k$ matrix of rank $r$, and

$$
z_{t-1}^{m}=\left[z_{t-1}^{\prime}, P_{1, T}(t) Z_{t-1}^{\prime}, P_{2, T}(t) z_{t-1}^{\prime}, \ldots, P_{m, T}(t) z_{t-1}^{\prime}\right]^{\prime} .
$$

The null hypothesis is: $\beta_{t}^{\prime}=\beta^{\prime}=0$, which implies no long-term relationship between the returns of REITs, general equities and direct real estate investments over the whole observation period. BIERENS and MARTINS (2010) suggest that the null hypothesis of time-invariant cointegration corresponds to $\xi_{i}^{\prime}=\left[\beta^{\prime}, O_{r, k, m}\right]$, so $\xi^{\prime} z_{t-1}^{m}=\beta^{\prime} z_{t-1}^{0}$, where $z_{t-1}^{0}=z_{t-1}$. The null hypothesis can be tested via a likelihood ratio (LR) test as follows:

$$
L R^{t v c}=-2\left[l_{T}(r, 0)-l_{T}(r, m)\right]
$$

where $\hat{l}_{T}(r, 0)$ is the log-likelihood value of the $\operatorname{VECM}(\mathrm{p})$ in the $\mathrm{m}=0$ case. $\hat{l}_{T}(r, m)$ is the loglikelihood of the VECM (p), where $z_{t-1}^{m}$ is given by Equation (8). In both cases, $r$ is the number of cointegration rank. In this paper, we choose $\mathrm{m}=1$, based on BIC criteria.

\section{Empirical Results}

\subsection{Data}

The data for our REIT total return indices come from NAREIT. The direct real estate investment total return indices come from the appraisal-based NCREIF index. The advantage of using appraisal-based indices is that they cover much longer periods than transaction-based indices. However, they may suffer from appraisal smoothing. Because this paper focuses on long-term characteristics, a longer sample period is critical for the estimation. Regarding the appraisal smoothing, Oikarinen, Hoesli, and Serrano (2011) note that "appraisal smoothing should not notably influence the cointegration test results, since in the long-run, the appraisers' views cannot diverge from the actual price level in a systematic manner." Therefore, we choose the appraisal-based indices. Appraisal-based indices have been used in literature which investigates the long-term relationship between REIT indices and stock indices (see e.g., GLASCOCK, LU, SO 2000; MORAWSKI, REHKUGLER, FÜSS 2008; OIKARINEN, HOESLI, SERRANO, 2011). However, we have to acknowledge that using appraisal-based indices may lead to an underestimation of the short-term relationship between REIT and stock indices. However, short-term relationship is not the focus of this paper.

It is also important to consider leverage. REIT indices include the impact of leverage, but direct real estate indices consist of unleveraged properties. HOESLI and OIKARINEN (2012) argue that the magnitude of leverage can affect the mean and the volatility of REITs. Additionally, time variation in the leverage may hinder the cointegration tests, and distort the estimated long-run parameters. Therefore, following HOESLI and OIKARINEN's (2012) method, we add leverage to the direct real estate market in order to make it more comparable to the stock market. The leveraged direct real estate investment index is defined as follows (HOESLI and OIKARINEN 2012):

$$
r_{e t}=\frac{r_{u t}-r_{d t} L T V_{t}}{1-L T V_{t}}
$$

where $r_{e t}$ is the leveraged direct real estate return in period $\mathrm{t}, r_{u t}$ is the unleveraged direct market 
return, $r_{d t}$ is the borrowing cost, calculated as the Moody's Baa-rated corporate bond yield, and $L T V_{t}$ is the loan-to-value ratio of REITs, calculated as the average total debt-to-asset ratio of REIT companies, weighted by market value. The debt-to-asset ratios for individual REIT companies come from Datastream. On average, REITs exhibited leverage of about 42\% from 1978 to 2008, with a maximum of $58 \%$ in 2007 Q4 and a minimum of $26 \%$ in 1986.

Data are quarterly. Total return series are first deflated using the CPI, and then log-transformed. We also include several fundamental variables: the inflation growth rate, the real interest rate, measured as the difference between the three-month T-bill yield and year-over-year inflation, and the default risk premium, calculated as the spread between BAA corporate bonds and the ten-year government bond yield.

Table 1 reports the descriptive statistics. The mean, standard deviation, skewness, and excess kurtosis are based on the deflated and differenced total return series. Obviously, because of appraisal smoothing and leverage, the direct real estate total return exhibits the lowest volatility. REIT returns and stock total returns are comparable to each other.

Table 1

Descriptive Statistics

\begin{tabular}{lcccccr}
\hline & Mean & Std & Skewness & $\begin{array}{c}\text { Ex. } \\
\text { kurtosis }\end{array}$ & 1_I $(0)$ & d_I(0) \\
\hline REITs & & & & & & \\
\hline d_reit_all & 0.0179 & 0.0695 & -0.328 & 0.227 & $0.407^{* * *}$ & 0.051 \\
\hline d_reit_equity & 0.0227 & 0.0701 & -0.146 & 0.515 & $0.190^{* *}$ & 0.025 \\
\hline d_reit_mortgage & 0.0029 & 0.1135 & -0.765 & 1.299 & $0.247^{* * *}$ & 0.097 \\
\hline $\begin{array}{l}\text { Direct Property } \\
\text { Investment }\end{array}$ & & & & & & \\
\hline d_npi_all & 0.0183 & 0.0216 & -1.292 & 4.315 & $0.656^{* * *}$ & 0.051 \\
\hline Stock & & & & & & \\
\hline d_S\&P 500 & 0.0218 & 0.0798 & -0.644 & 1.229 & $0.487^{* * *}$ & 0.084 \\
\hline d_Russell & 0.0129 & 0.1077 & -0.762 & 3.128 & $0.138^{*}$ & 0.021 \\
\hline Fundamentals & & & & & & \\
\hline d_tb & -0.0285 & 1.2386 & -0.726 & 7.746 & $0.250^{* * *}$ & 0.040 \\
\hline d_risk default & 0.0177 & 0.3012 & 0.988 & 3.873 & $0.151^{* *}$ & 0.052 \\
\hline d_infl_growth & -0.0001 & 0.0049 & -0.364 & 1.108 & $0.447^{* * *}$ & 0.027 \\
\hline
\end{tabular}

Notes: Instead of the level of total returns, we base the statistics summary, including the mean, standard deviation, skewness, and excess kurtosis, on the growth of total returns (log-differenced total returns). d_stands for the logdifferenced series. 1_I(0) stands for the KPSS unit root test statistics for logged total return series, GDP series, inflation growth series, risk default, and T-bill rate series. $\mathrm{d} \_\mathrm{I}(0)$ represents the KPSS unit root test statistics on the differenced series. ${ }^{* *},{ }^{* *}$, and ${ }^{*}$ denote significance at the $1 \%, 5 \%$, and $10 \%$ levels, respectively.

\section{Source: Own Calculation.}

Figure 1 shows the five-year rolling correlation of REITs with leveraged direct real estate returns, S\&P 500 returns and Russell Mid-cap returns. Obviously, REIT returns have a higher contemporaneous correlation with equity returns than with direct real estate investment returns, especially prior to 2000. The correlation with Russell Mid-cap return overwhelms the correlation with S\&P 500, as the REIT universe is essentially mid-cap value. Moreover, it is clear that the three correlations increased during the 2000s. In fact, during the 2003-2008 period, all three correlations rise to 0.8 . The increase in the correlation with S\&P 500 can be attributable to the event that several U.S. REITs were included in the S\&P 500 index during this period. Another reason for the dramatic increase in the correlations is the impact from common macro-factors. For example, the historically low interest rate in the early 2000s triggered risk-taking behaviours that spurred easy credit for banks to make loans. The large amount capital inflow to real estate sector lead to real estate bubbles, which drove the returns of both direct and indirect real estate investments.

\subsection{Long-Run Relationship}

We estimate the long-run relationship by means of a VECM model. We set the number of lags for the 
autoregressive term to 1 , based on BIC information criteria. The Johansen trace test suggests one cointegration relationship under the unrestricted trend specification. As Table 2 shows, the TV-VECM model achieves higher log-likelihood values than the TI-VECM model. The LR test suggests that the improvement is significant at 6 degrees of freedom, which indicates a time-varying long-run relationship.

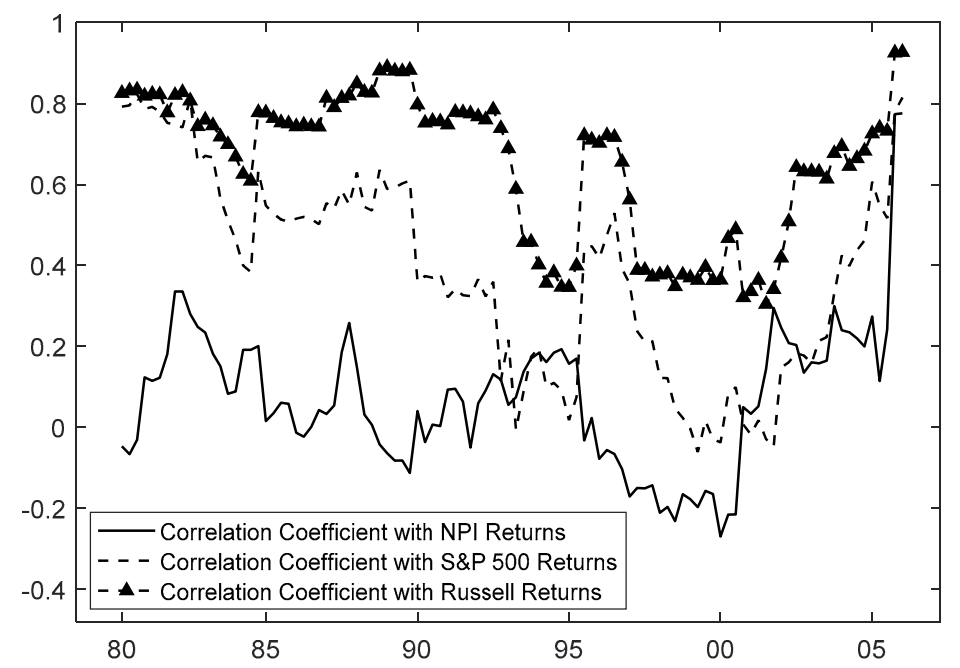

Fig. 1. Contemporaneous Correlation Coefficient with Equity Returns and NPI Returns. Source: own calculation.

Table 2

Time-Invariant and Time-Varying Vector Error Correction Models

\begin{tabular}{|c|c|c|c|c|c|c|}
\hline \multicolumn{7}{|l|}{ TI-VECM } \\
\hline & REITs & CPI & $\begin{array}{r}\text { Default } \\
\text { Risk }\end{array}$ & $\begin{array}{r}\text { Interest } \\
\text { Rate }\end{array}$ & NPI & S\&P 500 \\
\hline$\beta$ & 1.000 & $\begin{array}{r}-0.4490^{* * *} \\
(0.0532)\end{array}$ & $\begin{array}{r}-0.1352^{* * *} \\
(0.0429)\end{array}$ & $\begin{array}{r}-0.0961^{* * *} \\
(0.0166)\end{array}$ & $\begin{array}{c}0.7007^{* * *} \\
(0.1260)\end{array}$ & $\begin{array}{r}-0.1237 \\
(0.1073)\end{array}$ \\
\hline$\alpha$ & $\begin{array}{l}-0.1088^{*} \\
(0.0517)\end{array}$ & $\begin{array}{c}-1.2336^{* * *} \\
(0.2752)\end{array}$ & $\begin{array}{r}-0.2998 \\
(0.1928)\end{array}$ & $\begin{array}{r}0.1209 \\
(0.6782)\end{array}$ & $\begin{array}{l}0.0358^{\star * *} \\
(0.0100)\end{array}$ & $\begin{array}{r}-0.0572 \\
(0.0460)\end{array}$ \\
\hline Johansen test & 1 & & & & & \\
\hline $\mathrm{BIC}$ & -3.50 & & & & & \\
\hline Log-likelihood & 384.94 & & & & & \\
\hline \multicolumn{7}{|l|}{ TV-VECM } \\
\hline$\alpha$ & $\begin{array}{l}-0.1492^{*} \\
(0.0756)\end{array}$ & $\begin{array}{c}-2.0578^{* * *} \\
(0.4673)\end{array}$ & $\begin{array}{r}0.6036 \\
(0.3371)\end{array}$ & $\begin{array}{r}0.1278 \\
(1.1904)\end{array}$ & $\begin{array}{c}0.0917^{\text {*** }} \\
(0.0163)\end{array}$ & $\begin{array}{r}-0.1204 \\
(0.0806)\end{array}$ \\
\hline Log-likelihood & 399.02 & & & & & \\
\hline $\mathrm{BIC}$ & -3.51 & & & & & \\
\hline LR test & $28.16^{* * *}$ & & & & & \\
\hline
\end{tabular}

Notes: This table reports the parameters based on a TI-VECM model and a TV-VECM model. REITs stands for REIT indices, CPI for CPI growth rate, default risk for the spread between BAA corporate bonds and the ten-year government bond yield, interest rate for the three-month T-bill rate, NPI for direct real estate indices, and S\&P 500 for the equity index. $\beta$ is the cointegration coefficient, and $\alpha$ is the error correction term coefficient. The coefficients for the autoregressive terms are available from the authors upon request. Standard deviations are in parentheses. ${ }^{* * *}, * *$, and * denote significance at the $1 \%, 5 \%$, and $10 \%$ levels, respectively.

\section{Source: Own Calculation.}

Figure 2 illustrates time-varying $\beta$ s. The dashed line denotes the bootstrapped upper and lower $90 \%$ confidence intervals. Furthermore, because $\beta$ may be non-normally distributed, we use a nonparametric bootstrap (the wild bootstrap) to generate the confidence interval. The bootstrap runs 500 times. 


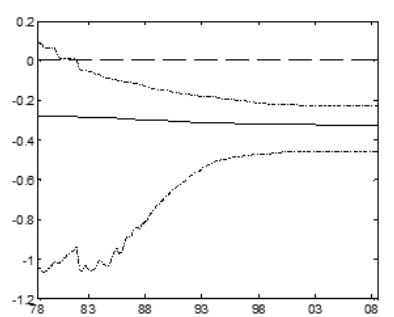

a. $\mathrm{CPI}$

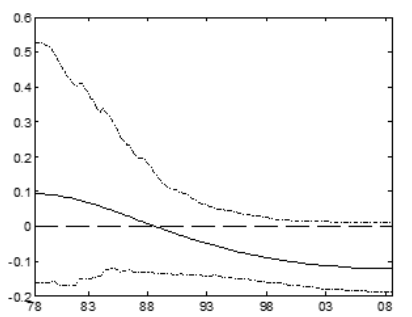

b. Default Risk Premium

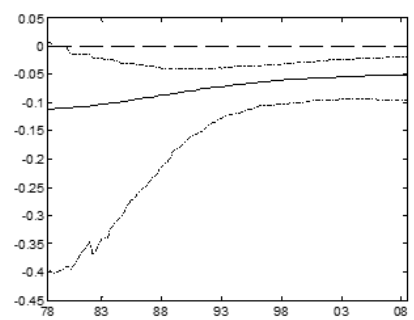

c. Interest Rate

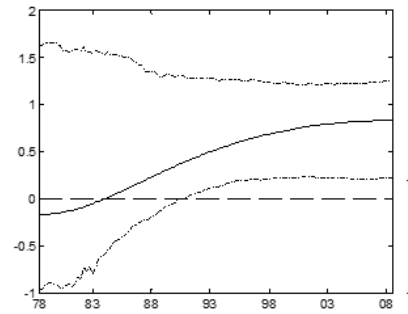

d. NPI

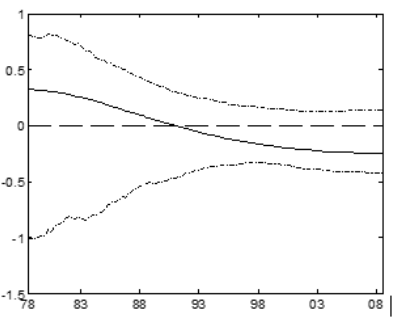

e. $S \& P 500$

Notes: The solid line shows estimated long-run elasticity. The dashed line denotes the bootstrapped upper and lower $90 \%$ confidence intervals, which are generated based on a non-parametric bootstrap (the wild bootstrap). The bootstrap runs 500 times.

Fig. 2. Time-Varying Long-Term Elasticity. Source: own calculation.

We observe that the elasticity of direct real estate investments has obviously increased. It first became significant in 1991. In 2008, a 1\% increase in direct real estate investment returns was associated with a $0.80 \%$ increase in REITs in the long term. The intensity was around three times as strong as in 1991.

There are two reasons for this increase in the long-term elasticity of NPI on REITs. First, the U.S. REIT market has slowly matured. When REITs were first introduced and little was yet known about them, they tended to simply follow the major market indices. However, as more information has become readily available, their investment characteristics have changed along with investor perceptions (CLAYTON, MACKINNON 2009). We believe their nature is now better reflected.

Second, concurrently, REIT management has become more professional. There has been a move in the industry toward specialization in, e.g., one particular type of REIT, or in two closely related property types (e.g., industry and office). During the 1980s, REITs tended to be diversified by property type. But by 2008, less than $8 \%$ were diversified. Consequently, the performance of REITs is now tied more directly to that of their underlying markets.

Regarding stock performance, we find that long-term elasticity was insignificant over the period of from 1980 to 2008. Recent studies have found that stock and REIT returns have become more similar because of increased institutional involvement and the more developed size of REITs. But the major impact of these changes is documented as trade noise (CLAYTON, MACKINNON 2009), investor sentiment spillover (AMBROSE, LEE, PEEK 2007), and extreme events (SIMON, NG 2009). These influences may heavily affect the short-term performance of REITs, but our results suggest that they are unlikely to change the nature of REITs in the long run.

Additionally, we note that inflation growth is significantly negatively correlated with REITs, and elasticity is quite stable at 0.3 . A negative relationship between REIT performance and inflation was also found by FAMA (1981), BALDUZZI (1995) and FUGAZZA, GUIDOLIN and NicoDANO (2007). Furthermore, we find that REIT total returns are significantly negatively affected by interest rate, but the influence has decreased slightly. Elasticity was around 0.1 during the 1980s, but it dropped to around 0.05 in the 2000s.

Figure 3 illustrates the deviation of REITs from this long-term relationship. We can see that the deviation based on the time-varying long-run elasticity is much smaller than the deviation calculated using constant elasticity, especially during the mid-1990s and mid-2000s. OIKARINEN, HOESLI and SERRANO (2011) found a "large and long-lasting" deviation from the long-run relationship between 
NAREIT and NCREIF since the beginning of the "new era of REITs." Our empirical results imply that some of the deviation may be attributed to the changing nature of REITs.

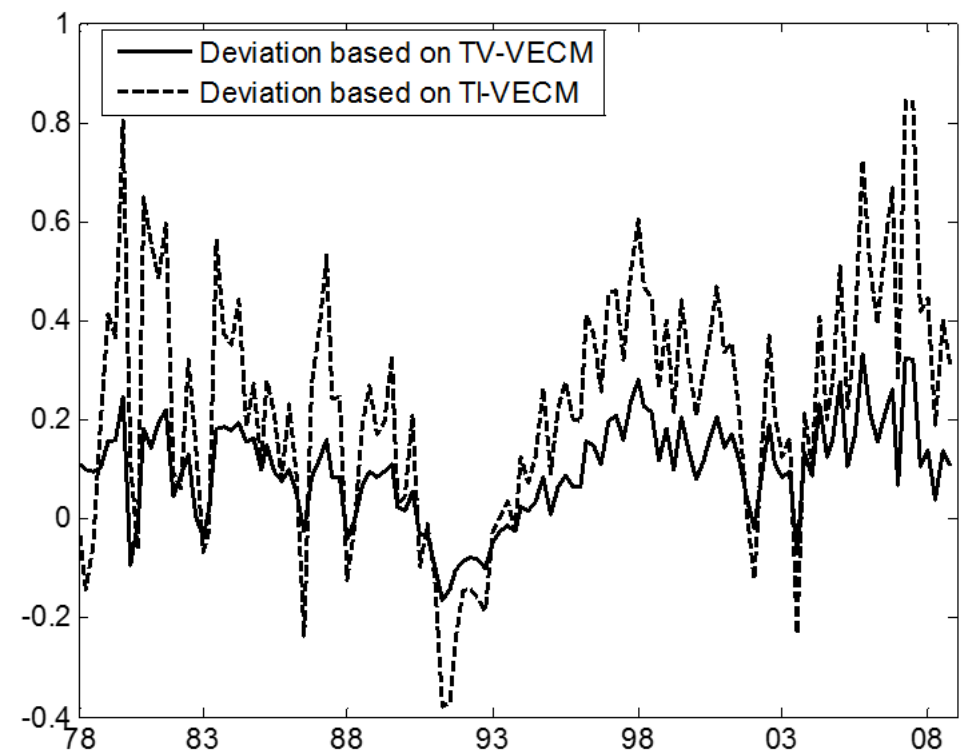

Fig. 3. Deviation of REITs from Long-Run Equilibrium. Source: own calculation.

\subsection{Variance Decomposition}

We use variance decomposition to further illustrate how REIT performance is affected by other asset classes. The Cholesky decomposition order is as follows: inflation growth-NPI total return-stock total return-default risk-T-bill rate-REIT total return. The results are robust with other orders.

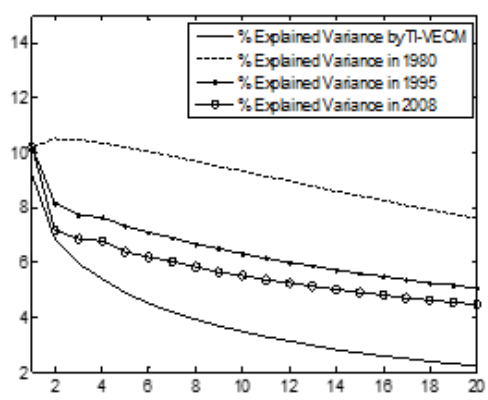

a. Variance Explained by CPI Growth

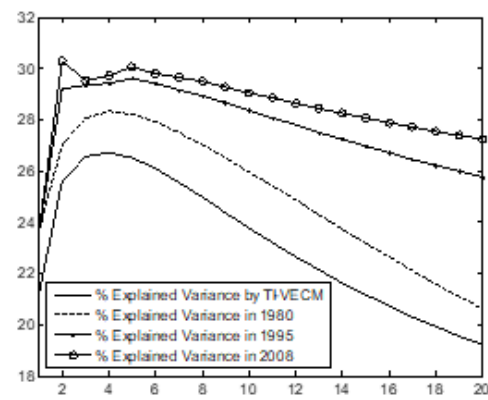

d. Variance Explained by NPI

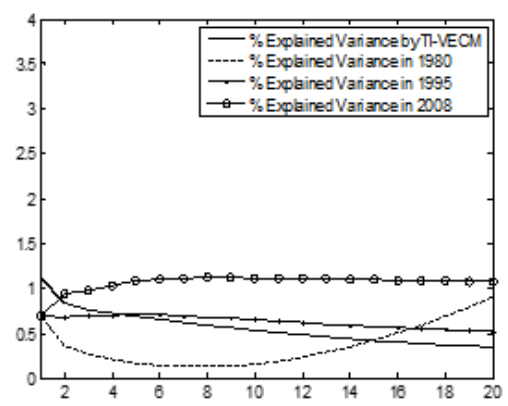

b. Variance Explained by Credit Risk

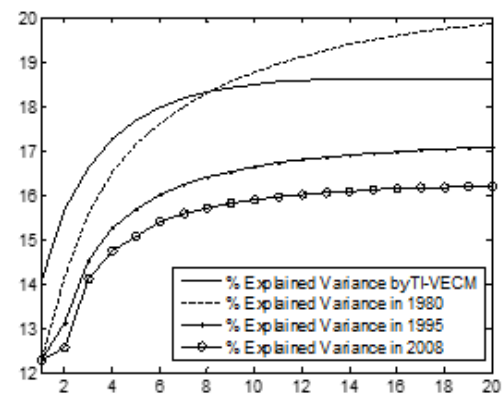

e. Variance Explained by S\&P 500

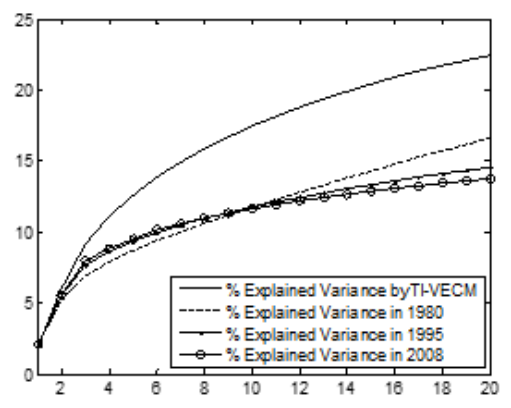

c. Variance Explained by Interest Rate

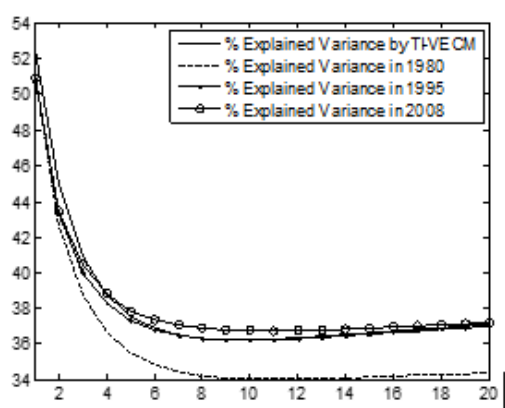

f. Variance Explained by REITs

Fig. 4. Variance Decomposition. Source: own calculation.

Because long-run elasticity varies in each quarter, we note that variance decomposition also changes over time. Figure 4 illustrates the decomposed forecasting variance of REIT return in 1980, 1995, and 2008, respectively. As a comparison, we also show the variance decomposition by means of the TI-VECM model. In general, we observe that the underlying property market explained an increasingly larger proportion of REIT variance from 1980 to 2008, while the variance attributed to the 
stock market declined.

In 1980, the stock market and the underlying equity market played similar roles in explaining REIT variations. Both explained approximately $20 \%$ of the forecasting variance in twenty quarters ahead. In 2008 , the contribution by NPI performance increased to $27 \%$, but the contribution by stock performance dropped to $16 \%$. If we assume constant long-run elasticity, we may overestimate the influence from stock performance, while underestimate the impact from the underlying real estate market, especially during the 2000s.

Regarding the portion of variance explained by other variables, we observe that CPI growth and default risk explained less than 10\%. The interest rate explained approximately $16 \%$ in the next twenty quarters, which is similar to the contribution from equity market performance.

\subsection{Robustness Checks}

\subsubsection{Structural Break}

In our TV-VECM model, long-run elasticity is assumed to change gradually and smoothly according to the Chebyshev time polynomial. However, a structural break may be an alternative explanation. In order to check the breakpoint in the residuals of the overall equation system, we use the multivariate breakpoint Chow test (Candelon and Lütkepohl, 2001). The BP Chow test compares the determinants of the covariance matrix of residuals from the TV-VECM model in the full sample and the subsample. The null hypothesis is that adding the breakpoint cannot substantially improve the model's fit. We try several quarters, from 1990Q2 to 1994Q2, but find no significant breakpoints (Table 3).

Table 3

Multivariate Breakpoint Chow Test

\begin{tabular}{rr}
\hline Given Period & Test \\
\hline 1990Q2 & 0.211 \\
\hline 1991Q2 & 0.279 \\
\hline 1993Q2 & 0.320 \\
\hline 1994Q2 & 0.360 \\
\hline
\end{tabular}

Notes: The multivariate breakpoint Chow test checks the given period. The null hypothesis is that there will be no significant change in the coefficients before or after the given period. * denotes significance at the $10 \%$ level.

\section{Source: own calculation.}

\subsubsection{RUSSELL 2000 Total Return Index}

Clayton and MacKinnon (2003) suggest that REIT performance is more strongly affected by small-cap stocks than the overall stock market. As a robustness test, we next construct our TV-VECM model using RUSSELL 2000 total returns. The Johansen trace test suggests one cointegration relationship, where the LR statistic is 26.06, which is significant at 6 degrees of freedom. This indicates a timevarying long-run relationship (Table 4).

Table 4

Robustness Checks

\begin{tabular}{|c|c|c|c|c|c|c|}
\hline \multicolumn{7}{|c|}{ Model with RUSSELL 2000} \\
\hline & REITs & CPI & $\begin{array}{r}\text { Default } \\
\text { Risk }\end{array}$ & $\begin{array}{r}\text { Interest } \\
\text { Rate }\end{array}$ & NPI & $\begin{array}{r}\text { RUSSELL } \\
2000\end{array}$ \\
\hline$\alpha$ & $\begin{array}{r}-0.1361 \\
(0.0846)\end{array}$ & $\begin{array}{r}-1.6889^{* * *} \\
(0.4629)\end{array}$ & $\begin{array}{r}0.5416 \\
(0.3195)\end{array}$ & $\begin{array}{r}-0.4145 \\
(1.1106)\end{array}$ & $\begin{array}{l}0.0860^{\text {*** }} \\
(0.0155)\end{array}$ & $\begin{array}{r}-0.1435 \\
(0.1026)\end{array}$ \\
\hline Log-likelihood & 386.47 & & & & & \\
\hline LR test & $26.06^{\star \star \star *}$ & & & & & \\
\hline \multicolumn{7}{|c|}{ Model without Economic Variables } \\
\hline TV-VECM & REITs & NPI & S\&P 500 & & & \\
\hline$\alpha$ & 0.1085 & $0.1106^{\text {*** }}$ & 0.0666 & & & \\
\hline
\end{tabular}




\begin{tabular}{lrrr}
\hline & $(0.0928)$ & $(0.0154)$ & $(0.0817)$ \\
\hline Log-likelihood & 623.06 & & \\
\hline LR test & $32.06^{\text {**t }}$ & & \\
\hline
\end{tabular}

\begin{tabular}{|c|c|c|c|c|c|c|}
\hline \multicolumn{7}{|l|}{ Equity REITs } \\
\hline TV-VECM & REITs & CPI & $\begin{array}{r}\text { Default } \\
\text { Risk }\end{array}$ & $\begin{array}{r}\text { Interest } \\
\text { Rate }\end{array}$ & NPI & S\&P 500 \\
\hline$\alpha$ & $\begin{array}{r}-0.2405^{* * *} \\
(0.0877)\end{array}$ & $\begin{array}{r}-2.3094^{* * *} \\
(0.4816)\end{array}$ & $\begin{array}{r}-0.8495^{* * *} \\
(0.3383)\end{array}$ & $\begin{array}{r}-0.6591 \\
(1.2073)\end{array}$ & $\begin{array}{l}0.0705^{\text {*k* }} \\
(0.0175)\end{array}$ & $\begin{array}{r}-0.1824^{* * *} \\
(0.0798)\end{array}$ \\
\hline Log-likelihood & 403.67 & & & & & \\
\hline LR test & $31.02^{* \star *}$ & & & & & \\
\hline
\end{tabular}

\begin{tabular}{lrrrrrr}
\hline Mortgage REITs & \multicolumn{7}{c}{ CPI } & $\begin{array}{r}\text { Default } \\
\text { Risk }\end{array}$ & $\begin{array}{r}\text { Interest } \\
\text { Rate }\end{array}$ & \multirow{2}{*}{ NPI } & \multirow{2}{*}{ S\&P 500 } \\
\hline TV-VECM & \multirow{2}{*}{ REITs } & \multicolumn{1}{c}{ CPI } & & \\
\hline$\alpha$ & 0.0804 & 0.0129 & $-0.4250^{* * *}$ & 1.2762 & $0.0818^{* * *}$ & $0.1582^{* * * *}$ \\
& $(0.0731)$ & $(0.3382)$ & $(0.2169)$ & $(0.7630)$ & $(0.0090)$ & $(0.0500)$ \\
\hline
\end{tabular}

\begin{tabular}{lr}
\hline Log-likelihood & 340.93 \\
\hline LR test & $18.80^{* * *}$
\end{tabular}

Notes: This table reports the parameters based on alternative TV-VECM models. REITs stands for REIT indices, CPI for CPI growth rate, default risk for the spread between BAA corporate bonds and the ten-year government bond yield, interest rate for three-month T-bill rate, NPI for direct real estate indices, and S\&P 500 for the equity index. $\beta$ is the cointegration coefficient, and $\alpha$ is the error correction term coefficient. The coefficients for the autoregressive terms are available from the authors upon request. Standard deviations are in parentheses. ${ }^{* *}, * *$, and * denote significance at the $1 \%, 5 \%$, and $10 \%$ levels, respectively.

Source: own calculation.

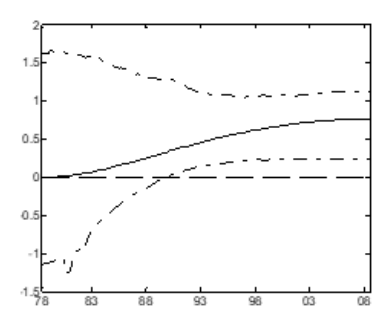

a) NPI

Fig. 5-1 Time-Varying Elasticity of NPI and RUSSELL 2000 to REITs

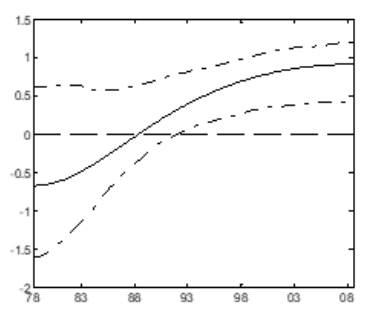

a) NPI

Fis. 5-2 Time-Varying Elasticity without Economic Variables

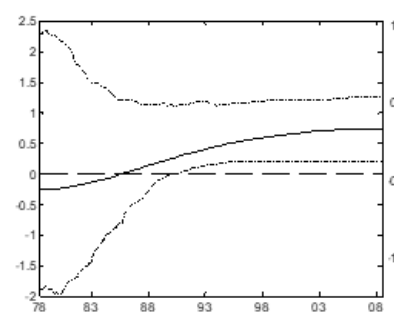

a) NPI

Fig. 5-3 Time-Varying Elasticity of Equity REITs

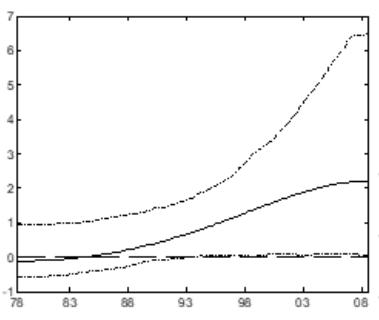

a) NPI

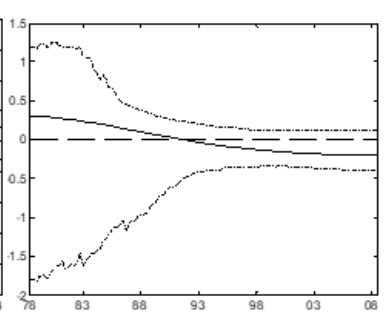

b) $\cos 500$

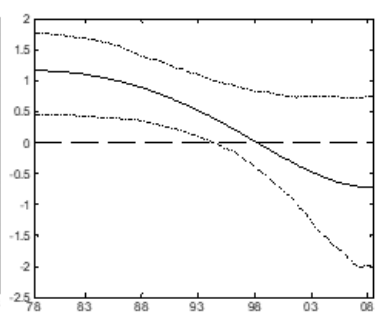

b) $\ln 58 \times P 500$

Fig. 5. Robustness Checks.

Notes: The solid line shows estimated long-run elasticity. The dashed line denotes the bootstrapped upper and lower $90 \%$ confidence intervals, which are generated based on a non-parametric bootstrap (the wild bootstrap). The bootstrap runs 500 times.

Source: own calculation.

Figure 5-1 reports the time-varying elasticity of NPI and RUSSELL 2000 total returns. The elasticity of NPI total returns has increased over time, becoming significant in 1990. In 2008, NPI elasticity 
reached 0.75; however, the long-term elasticity of RUSSELL 2000 is always insignificant. We find no significant difference between the RUSSELL 2000 and the S\&P 500 in terms of their long-term relationship with REITs.

\subsubsection{Common Economic Factors}

As a further robustness check, we analyze the nature of REITs without any economic factors. We therefore base the TV-VECM model only on REITs, NCREIF, and the S\&P 500. The LR test indicates that the TV-VECM model can substantially improve the model's fit compared with TI-VECM.

The long-term elasticity series are illustrated in Figure 5-2. NPI total returns became significant in 1992 and in 2008; elasticity was about 0.92 . Moreover, equity total returns exhibited significant negative elasticity to REITs in the 2000s. The negative coefficient may be caused by the influence of some common economic variables, which we do not account for in this model.

\subsubsection{Equity and Mortgage REITs}

Next, instead of overall REITs, we construct the TV-VECM model on equity REITs and mortgage REITs, respectively. The equity REIT market experienced tremendous growth during the 1992-1997 period, and dominated the U.S. REIT market during the 2000s. This dramatic increase is attributable to the significant legislative changes made to REIT structures, which ultimately made REITs more attractive to institutional investors.

The results are reported in Table 4. We see that the time-varying cointegration can statistically significantly improve the model's fit compared with the constant cointegration model. As for the longterm relationship, the conclusion is similar to that for overall REITs. NPI elasticity became significant at the beginning of the 1990s, but the elasticity of the general equity market remained insignificant (Figure 5-3).

Regarding mortgage REITs, they made up about 30\%-40\% of U.S. REITs before the 1990s, but by 2000 , the proportion was less than $10 \%$. Similarly to equity REITs, mortgage REITs also exhibit significant long-term elasticity with NPI total returns since 1993. But we note that mortgage REITs were also significantly positively correlated with S\&P 500 total returns before 1994 (Figure 5-4).

\section{Conclusion}

Since their introduction, the market for U.S. REITs has gradually matured, with REIT investment characteristics undergoing a concurrent gradual maturation. As investors have become more aware of REITs and their diversification potential, they have shown increasing interest in this important asset class. Before REITs gained recognition, investors tended to just follow the general equity market. But as management has begun to, e.g., move toward property type specialization, REITs are now more likely to reflect the underlying property market.

This paper focuses on changes in the "nature" of REITs. We use a sample based on U.S. REIT total returns, NCREIF appraisal-based property investment total returns, and equity total returns from the 1980 to 2008 period, and find time-varying long-term relationships among the three asset categories.

The links between REITs and their underlying properties grew increasingly close from the 1980s through the 2000s. They first became significant at the beginning of the 1990s; by 2008, the elasticity to direct real estate investment increased to around 0.82 . However, the elasticity of the general equity market remained insignificant. Based on this time-varying relationship, REIT total returns deviate less from the equilibrium than in the case of a constant long-term relationship, particularly during the mid-2000s. This implies that some of the REIT deviations found in the previous literature may be explained by the changing nature of REITs.

The variance decomposition also demonstrates the increasingly close links to the underlying property markets over the long term. In the 1980s, the equity market and the underlying property market played similar roles in predicting REIT variations. In the 2000s, the performance of the underlying property market became more important. We posit that ignoring the change in the cointegration relationship may overestimate the influence of the equity market risk and underestimate the influence from the risk in the underlying asset market in the long run.

The long-term synchronicity between real estate securities and direct real estate implies that the primary characteristics of real estate investment persist despite the influence of stock or bond market movements. We thus conclude that the long-term benefit of REITs as diversifiers of direct real estate investments has diminished since the mid-1990s. However, REITs can still serve as an alternative 
investment for equities with long-term investments.

Finally, note that our model is somewhat restrictive in that it only allows for the change in longterm elasticity, while assuming a constant adjustment coefficient as well as constant short-term coefficients. However, as Bierens and Martins (2010) noted, this assumption would not cause bias in the estimated long-term relationships. Regarding the short term dynamics, since several previous studies have already investigated the short-term relationship between REITs and other assets, we do not discuss changes in the short term here but leave them for future research.

\section{References}

Alexander et AL., 2002, Conintegration and Asset Allocation: A New Active Hedge Fund Strategies. Financial Risk and Financial Risk Management. 16, pp.65-89.

Ambrose B.W., LEE D.W., PeEK J., 2007, Comovements after Joining an Index: Spillovers of Nonfundamental Effects. Real Estate Economics, 35, pp.57-90.

BALDUZZI J. 1995, Stock Returns, Inflation and the 'Proxy Hypothesis: A New Look at the Data. Economics Letters, 48, pp. 47-78.

BIERENS H.J., MARTINS L.F. ,2010, Time varying cointegration. Econometric Theory.

CANDELON B., LÜTKEPOHL H., 2001, On the Reliability of Chow-type Tests for Parameter Constancy in Multivariate Dynamic Models. Economics Letters. 73, pp.155-160.

Clayton, J., MacKinnon G., 2001, The Time-Varying Nature of the Link between REIT, Real Estate and Financial Asset Returns. Journal of Real Estate Portfolio Management, 7, pp.43-54.

Clayton J., MacKinnon G., 2003, The Relative Importance of Stock, Bond, and Real Estate Factors in Explaining REIT Returns. Journal of Real Estate Finance and Economics 27, pp.39-60.

Clayton J., MaCKinnON G., 2009, Real Estate Investment Trusts: The U.S. Experience and Lessons from the UK. IPF Research Report.

FAMA, 1981, Stock Returns, Real Activity, Inflation, and Money. American Economic Review, 71, pp.201231.

FISHER J., Geltner D., WeBB B., 1994, Value Indices of Commercial Real Estate: A Comparison of Index Construction Methods. Journal of Real Estate Finance and Economics, 9, pp.137-164.

FugazZa C., Guidolin M., NiCODANo G., 2007, Investing for the Long-run in European Real Estate. Journal of Real Estate Finance and Economics. 34: pp.35-80.

GHOSH C., MiLes M., SIRMANS C.F., 1996, Are REITs stocks? Real Estate Finance, 13(3), pp.13-25.

GLASCOCK J., LU C., So R., 2000, Further Evidence on the Integration of REIT, Bond and Stock Returns. Journal of Real Estate Finance and Economics, 20, pp.177-194.

Hoesli M., LizIERI C., MACGREgOR B., 2008, The Inflation Hedging Characteristics of US and UK Investments: A Multi-Factor Error Correction Approach. Journal of Real Estate Finance and Economics, 38, pp.183-206.

HOESLI M., OIKARINEN E., 2012, Are REITs real estate? Evidence from international sector level data. Journal of International Money and Finance, 31, pp.1823-1850.

HoEsli M., SERRANO C., 2007, Securitized Real Estate and its Link with Financial Assets and Real Estate. An International Analysis. Journal of Real Estate Literature, 15, pp.59-84.

JOHANSEN S., 1988, Statistical Analysis of Cointegration Vectors. Journal of Economic Dynamics and Control, 12: pp.231-254.

LI Y., WANG K., 1995, The predictability of REIT returns and market segmentation. Journal of Real Estate Research, 10, pp.471-482.

LiNG D.C., NARANJO A., 1999, The Integration of Commercial Real Estate Markets and Stock Markets. Real Estate Economics, 27, pp.483-515.

LiU C., MEI J., 1992, The Predictability of Returns on Equity REITs and Their Co-movement with Other Assets. Journal of Real Estate Finance and Economics, 5, pp.401-418.

MORAWSKI J., REHKUGLER H., FÜsS R., 2008, The nature of listed real estate companies: Property or equity market? Financial Markets and Portfolio Management, 22, pp.101-126.

OiKARINEn E., Hoesli M., SERRANO C., 2011, The Long-Run Dynamics between Direct and Securitized Real Estate. Journal of Real Estate Research, 33(1), pp.73-103.

ONG S.E., 1995, Singapore Real Estate and Property Stocks: A Cointegration Test. Journal of Property Research, 12, pp.29-39. 
Pagliari J.L., Scherer K.A., Monopoli R.T., 2005, Public versus Private Real Estate Equities: A More Refined, Long-Term Comparison. Real Estate Economics, 33(1), pp.147-187.

Quan D.C., TitMan S., 1999, Do Real Estate Prices and Stock Prices Move Together? An International Analysis. Real Estate Economics, 27(2), pp.183-207.

SCHÄTZ A., SEBASTIAN S.P., 2011, Eine VECM-Analyse der Interaktion von Immobilienaktien mit Direktanlagen, Aktienmarkt und Realwirtschaft. Zeitschrift für Immobilienökonomie 10(1), pp.83107., A VECM analysis of the interaction of real estate stocks with direct investments, the stock market and the real economy. Journal of Real Estate Economics)

SERRANO C., HoesLi M., 2012, Fractional Cointegration Analysis of Securitized Real Estate. Journal of Real Estate Finance and Economics, 44, pp.319-338.

SimON S., NG W.L., 2009, The Effect of Real Estate Downturn on the Link between REITs and the Stock Market. Journal of Real Estate Portfolio Management, 15(3), pp. 211- 219.

TSAI I.C., CHEN M.C., SING T. F., 2007, Do REITs behave more like real estate now? Working paper.

WeSTERHEIDE P., 2006, Cointegration of Real Estate Stocks and REITs with Common Stocks, Bonds and Consumer Price Inflation: An International Comparison, in: Rottke, N.B. (ed.) Handbook Real Estate Capital Markets, pp.59-74. 